Journal of Southeast Asian

\title{
"Love, Unsublatable"
}

May Yang

myang96@ucmerced.edu

Follow this and additional works at: https://docs.lib.purdue.edu/jsaaea

Part of the Bilingual, Multilingual, and Multicultural Education Commons

\section{Recommended Citation}

Yang, May (2021) "'Love, Unsublatable"," Journal of Southeast Asian American Education and Advancement. Vol. 16 : Iss. 1, Article 5.

DOI: $10.7771 / 2153-8999.1229$

Available at: https://docs.lib.purdue.edu/jsaaea/vol16/iss1/5

This document has been made available through Purdue e-Pubs, a service of the Purdue University Libraries. Please contact epubs@purdue.edu for additional information.

This is an Open Access journal. This means that it uses a funding model that does not charge readers or their institutions for access. Readers may freely read, download, copy, distribute, print, search, or link to the full texts of articles. This journal is covered under the CC BY-NC-ND license. 


\title{
ISAAEA, Journal of Southeast Asian American
Education and Advancement
}

Vol. 16 Iss. 1 (2021)

www.JSAAEA.org

\section{Creative and Literary Works}

\author{
"Love, Unsublatable"
}

\author{
May Yang \\ University of California, Merced
}

"Love recognizes no barriers. It jumps hurdles, leaps fences, and penetrates walls to arrive at its destination full of hope"

- Maya Angelou, January 11, 2013

I keep telling myself love is complicated on the edges of freedom, whatever that means. I had thrown a broom once, not at him but at his kitchen floor. Later, he would leverage himself against me with the scar I welded in his linoleum. With all his words he would point to it and name my past aggression abuse. I agreed.

When I threw that damned thing, it was because he accused me of missing my ex. The night before this chaos, I dreamed a shadow-man came to me and took the shape of an old lover. We sat near one another in a giant theater a few seats apart. He came to tell me goodbye, but as he spoke his words became muffled, so I called my (now also ex-) partner on a cell phone. I exited the theater in search of him. Every time I turned a corner I'd lose myself, and the street signs would change. It was strange and creepy. I was discouraged and lost; so incredibly lost. When I awoke, I immediately told my partner of this nightmare. That morning took a pause at silence, and proceeded with accusation.

My anger was not exactly centered on this false accusation; it was centered on a misunderstanding deeply rooted in the undead history of modern thought. It was not only a misunderstanding; it was a deep and long-standing violation against my person. I felt its duress in this moment of confusion between the two of us. I am a Hmong woman, and I grew up in shamanism. Here, in this place of being Hmong, dreams are a real space of knowing and a place of forethought and insight. As we argued in circles, I tried hard to explain to him that the dream was spiritual. It was telling. These were symbols and images my spirit guides gave me as warnings. Instead of hearing me, he insisted I was wrong and illogical. He interrupted my stories with the logic of modern psychology, and I began to feel crazy. He said I could ask anybody, and they

\footnotetext{
@)

SDRERIIGHISRESERNEDR Readers are free to copy, display, and distribute this article, as long as the work is attributed to the author(s) and the Journal of Southeast Asian American Education \& Advancement, it is distributed for non-commercial purposes only, and no alteration or transformation is made in the work. More details of this Creative Commons license are available at http://creativecommons.org/licenses/by-nc-nd/3.0/. All other uses must be approved by the author(s) or JSAAEA. Journal of Southeast Asian American Education \& Advancement, Vol. 16. Iss. 1. (2021) ISSN: 2153-8999
} 
would agree my dream simply meant I missed someone. I must have held onto that person mentally. What is it to even have a hold on someone?

We were both clearly hurt. Our hurt came from different spaces of knowing, complicating what could be shared between us as simple truth. The more he emphasized my wrongness, which ultimately translated to me as jealousy, the more frustrated I became. I was not wrong, and he wasn't either in his own knowing; whatever it was and however it constituted him. How could we be together in our differences? Deep down I knew something beyond my voice was silenced. My entire ancestral assemblage fell behind the backdrop of a deeply Eurocentric logic of reason. I must have been mad to believe these were messages from the spiritual realm. Seeds of doubt took root, and I knew there was nothing to argue when I had no reason. We could not find one another with our words, so I threw the broom. I want to believe that if I hadn't thrown the broom, I would have been in control of myself or have not given up my power. I could have just walked away. In hindsight, there was no way to have rendered legible these things my ancestors carried over to leverage me in this world.

This wasn't the first time I encountered this particular misreading. My first relationship involved someone attempting to relate to me by way of their friend, who practiced witch-type magic. The second, involved my ex's entire family arguing with me in their living room on whether or not animal sacrifice was moral. In my most recent relationship, which also ended in failure, I was accused of actually being a witch. Gaslighting was a term I'd learn much later. When I picked up that word I hoped it would fit this space which refused me and denied me my own reality. It didn't. I've learned to accept that some cannot see the stories I had to carry - stories which were always already obfuscated by modern narratives of shamanism as backwards, illogical, and uncivilized. At times, I wonder if this very narrative of incivility justified the use of Hmong men and children as guerilla fighters in the U.S. Secret War, a war later recognized as the Laotian Civil War.

Where do truths reveal themselves? When I asked my mother why her younger brother decided to stay in Thailand after refugee resettlement, she simply said he made the dumb decision to do so. It was only on my trip to visit him in 2015 that I'd learn his story. I remember sitting in the backseat of his truck sometime in early December of that year. As the evening settled in, my uncle began blanketing my mind with textures of his past. The truck bumped along dirt roads as we made our way back from having visited the old Chiang Kham refugee camp, now turned rubber tree plantation. He told us of how he chose asylum in Thailand, changing his family's Hmong name to Thai. I now have a cousin named Chiang, and another one named Kham. Maybe naming is another way to remember what was once home. Later, I came to understand how proud my uncle was that his last child was born outside of a camp. Ultimately, my uncle chose to stay in Thailand on the condition his parents would also stay. He made the decision to sacrifice opportunities in the U.S. to care for them in the camp. At the time of his decision, they had not wanted to leave what was familiar.

This is also when I found out my parents initially intended to sponsor his family into the U.S., but opted for the older uncle for whatever reason. In these narratives, circulating the displacement, rupture, and disconnect between us there are three key perspectives: the first being his decision to care for my grandparents out of love and obligation to them as a son; the second is a less likely reality, but frames my parents as prioritizing the older brother instead of him; lastly, it was neither of these circumstances, and he simply opted out of the U.S. for Thailand - also highly unlikely. No one wanted to take responsibility, and no one knew where to place the blame. My grandparents ended up coming to the U.S. after 2005, and because he had already processed 
paperwork for asylum in Thailand, he and his family were stuck there. We would like to believe there exists some kind of freedom of choice in any of these perspectives. But life is complicated and messy on the edges of freedom; especially in refugee camps, and most especially after these places have come and gone. You can't just say, "I love you," pack up, and move across an entire ocean together. All I know now is how to hold the pieces of these stories inside of me so as to find their truths, even as they change.

Oh, I forgot to tell you how my father had sent a cassette-tape recording to my uncle before resettlement. In the recording, my father explained to my uncle that the reason my grandparents were choosing to stay in Thailand was because they had a nostalgic longing for their homeland in Laos. He expressed that this longing could somehow, "save them from the bullet of a communist." Through this love, it might be possible that, "tripping on the root of a Laotian tree trunk might save them from the whirl of a communist bullet." I guess this cassette had been playing in ear shot of my grandfather, who came up to my uncle and asked who'd sent it. As soon as he heard my father's name mentioned he grabbed the cassette player, pulled out the cassette, and tossed it on the ground. He was decisive with his anger, splitting the story in half with the ax in his right hand. My uncle became deeply upset, being the sentimental person that he was. He disagreed with my grandfather. He argued that this was a recording from his brother-in-law, and he had wanted to keep the recording no matter what was said. Who knew when they would get to see my father again? My grandfather was a man of few words, and simply said it was a waste to hear such a farce of a story. In the back seat of the truck, I tried to fit the pieces together. All the while, my uncle expressed his regret for not getting to see my father before his passing. He had attempted to put the broken cassette back together, but it was a futile attempt. He wished my grandfather never split that cassette in half so that maybe, I too could have listened, because it was a good story and somewhat true.

One of the biggest lies in modern history is the concept of true love. And because it might exist somewhere out there in the ether, we could somehow aspire towards it. How dangerous and strangely comforting. Sometimes I believe it exists just to keep moving. But this is a brief hold, and constantly interrupted by my grandmother. Her interruptions are grand gestures, offering me a way to move without it.

In early October of 2019, while backing out of my mom's driveway, I peeped my grandmother walking down the road towards the house. Instead of speeding out and rushing back home, I chose to take a break in the convoluted space of my life, which was so incredibly regulated by the University schedule I'd forgotten what a break meant. I stepped out the car, and rushed to her because she was the realest moment I'd peeped in a goddamn while. We smiled at one another, and I hugged her and berated her for not inviting me on her evening walk. She simply smiled, and I asked her to stay at my mother's house and to never leave us. Ever since my grandfather passed she'd been moving from one place to another, staying at either of my uncle or aunt's house. Instead of agreeing with me, she looked at me and said, "I'm done. I can't live anymore and I just want to go. I'm ready." There was a break for silence, and then I understood. We looked at one another some more and giggled. I knew faintly of what it felt like, always having to pack up and go. Obviously, not in the same way as her. I've moved up and down California over 20 times since 2009. Even now I'm packing. I told her, "Yeah, I can't stay in the same place for long. I keep moving around too." I'd never seen a woman with gold in her eyes until that day, but there was a knowing. Love wasn't enough to make her stay, and when a woman knows what she knows, you couldn't tell her twice to believe anything else. She was done. So I said, "Ok grandma, but you 
stay a little longer for me. I'm selfish and I'll miss you." We held each other and laughed some more. We knew it wasn't her time. She gave me a kiss and we parted at goodbye.

She told me once, that the best place she ever lived was in the Wat Tham Krabok refugee camp in Thailand. It was the seventh and final house my grandfather had built since they'd been married. He even used slabs of stone to build a bath house. All of her children and grand children had been resettled elsewhere, and they had that space all to themselves. She sold candy in front of their home during the day, and slept on the roof beside him during hot seasons. When I finally visited this home in 2015 with my uncle, I saw the large slabs of stone taking shape as pieces of their home. Most of the structure was gone, but the stone, including the bath house, remained. Grandfather carried every slab of stone on his own, one by one on his back, to build it. Uncle expressed this labor is the reason it remains. Even when Hmong people were forcibly repatriated in 2005, when their homes were demolished, and their deceased were exhumed from burial sites, large sections of grandfather's house remained. Across the small dirt path was an opening in the ground where one of grandmother's closest friends had been buried. My uncle and I crossed this path. Standing at the edge desecration, we held out a space for silence in our throats. I watched my uncle, and learned how silence had become a way to confront loss.

I've learned now, how to never reduce our imagination to the order of things. When you are fueled by the desire to live and love, there clearly isn't a right or wrong way to move across entire nations in search of home. Had my grandparents believed borders were logical boundaries of exclusion or inclusion, they never would have found their sense of home on the run. In their togetherness, home took a brief hold in a refugee camp. Maybe love is a deep consideration of how we can begin to reach into the porous recesses of others' memories, of their backs grounding and lifting various constitutions of being and belonging, of their desires and affirmations, and of their forthcomings and never just shortcomings. It's possible it is simply a recognition of life as complicated and messy. In the contemporary moment, we are perpetually moved to ask, what is healthy love? I wonder if some form of healthy love can be quantified against a more tangible form of unhealthy love. All the literature and research on healthy relationships tend towards a delineation of unhealthy love. I might know more now about trauma bonding than I ever will about love, but some things are better understood in silence, rather than iterations of knowing.

Nevertheless, love for me right now is simply how we go about assembling a story to constitute ourselves and others. They aren't always consistent - these stories. If we prescribe or ascribe a truth to love or a right way to love, it may border incongruent moments of loving in this world which cannot be recognized in the language or ways of being we have been taught. Borders are unfixed, and we must remember how to cross them and be in proximity with one another, rather than dominate each other. My mother had been sitting beside me in the back of my uncle's truck, and when she took in his story of betrayal and abandonment, she held out a space for it to sit beside her own. She did not put up a defensive structure in the shape of disagreement or anger. She simply said, "Yes, you're right. It's difficult, I know. I was worried, I've been worried. I love you. I love your family." I learned to recognize the remains of my grandparents' home as remainders of magnificence among ruin, rather than loss.

This remainder disrupts the attempted erasure of a lived experience, just as love disrupts the call to order in modern life - a life which seeks to silence and erase people in their aliveness. At times, love interrupts our own narrative so we can sit beside one another. We can be together in our differences with humility and forgiveness. Love is how we assemble belonging in the world, and how we find one another across our differences on this earth. Love is unsublatable, in that there are pieces of us and each other which cannot be discarded or assimilated to smooth out the 
unevenness constituting us. Love, in all the strange ways we are done and undone by it, is always arriving and always full of hope. Nevertheless, to enter into a state of arrival requires an act of letting go. So, I let go of old lovers and places I've once named home - recognizing now, how transmutations take shape when love becomes a gesture of release, liberating us.

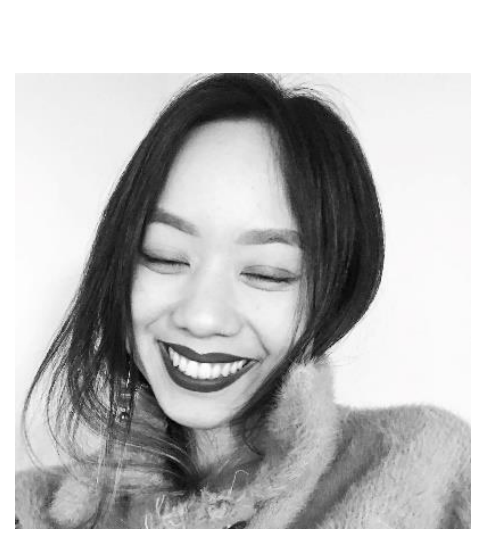

About the Author

May Yang is an artist and a scholar who publishes under the nom de plum hauntie. Yang's debut collection, To Whitey and the Cracker Jack (Anhinga Press, 2017), was selected by Evie Shockley for the 2016 Robert-Dana Anhinga Poetry Prize. Her work has also appeared in the Academy of American Poets and Poetry Moves (Ethos Books Press, 2020). Currently, she is a graduate student at the University of California, Merced in the department of Interdisciplinary Humanities. Working at the intersection of Critical Race and Ethnic Studies and Critical Refugee Studies, her research centers on the ways in which Hmong artistic practices provide a method and praxis for generating Hmong onto-epistemologies that ultimately undermine colonial and imperial powers. 


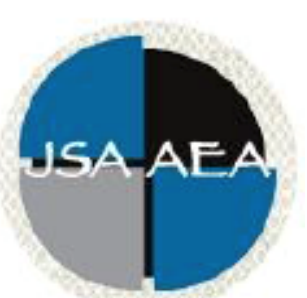

Vol.16 Iss.1 (2021)

\section{Journal of Southeast Asian American Education and Advancement}

\author{
Editor \\ Dr. Wayne E. Wright \\ Purdue University \\ Associate Editors \\ Dr. Chhany Sak-Humphry \\ University of Hawaii at Manoa \\ Dr. Phitsamay Sychitkokhong Uy \\ University of Massachusetts, Lowell \\ Book Review Editor \\ Dr. Vichet Chhuon \\ University of Minnesota \\ Creative Works Editor \\ Bryan Thao Worra \\ Lao Assistance Center \\ Journal Manager \\ Chen Li \\ Jeffrey Sovan Wright \\ Purdue University
}

\title{
Editorial Review Board
}

\author{
Dr. Steve Arounsack \\ California State University, Stanislaus \\ Dr. Sovicheth Boun \\ Salem State University \\ Dr. Virak Chan \\ Purdue University \\ Dr. Loan Dao \\ University of Massachusetts Boston
}

\author{
Dr. Carl L. Bankston III \\ Tulane University \\ Dr. Phala Chea \\ Lowell Public Schools \\ Dr. George Chigas \\ University of Massachusetts, Lowell \\ Dr. Hien Duc Do \\ San Jose State University
}




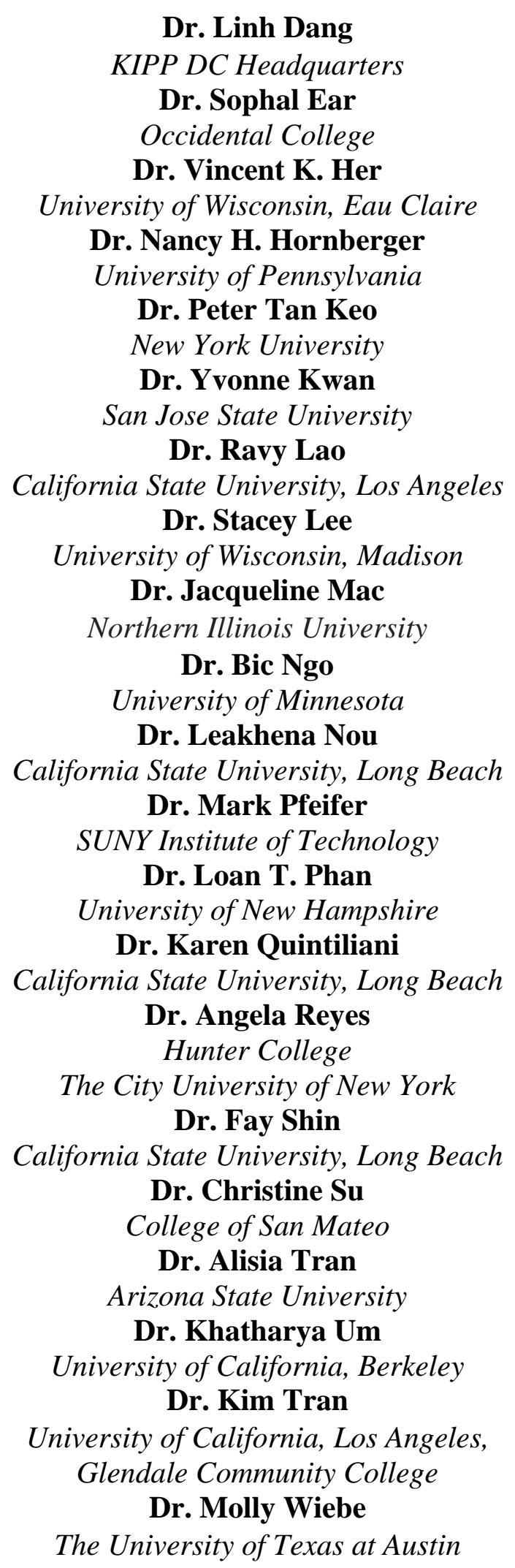

Dr. Linh Dang

KIPP DC Headquarters

Dr. Sophal Ear

Occidental College

Dr. Vincent K. Her

Dr. Nancy H. Hornberger

University of Pennsylvania

Dr. Peter Tan Keo

New York University

Dr. Yvonne Kwan

Dr. Ravy Lao

Dr. Stacey Lee

Dr. Jacqueline Mac

Dr. Bic Ngo

University of Minnesota

Dr. Leakhena Nou

Dr. Mark Pfeifer

Dr. Loan T. Phan

University of New Hampshire

Dr. Karen Quintiliani

Dr. Angela Reyes

Hunter College

Dr. Fay Shin

Dr. Christine Su

College of San Mateo

Arizona State University

Dr. Kim Tran

Dr. Zha Blong Xiong

University of Minnesota
Dr. Changming Duan

University of Missouri-Kansas City

Dr. Sothy Eng

Lehigh University

Dr. Jeremy Hein

University of Wisconsin, Eau Claire

Dr. Peter Nien-Chu Kiang

University of Massachusetts, Boston

Dr. Kevin K. Kumashiro

University of Illinois, Chicago

Dr. Ha Lam

Independent Scholar

Dr. Jonathan H. X. Lee

San Francisco State University

Dr. Monirith Ly

Royal University of Phnom Penh

Dr. Sue Needham

California State University, Dominguez Hills

Dr. Max Niedzwiecki

Daylight Consulting Group

Dr. Clara Park

California State University, Northridge

Dr. Giang Pham

University of Massachusetts Amherst

Dr. Malaphone Phommasa

University of California Santa Barbara

Dr. Kalyani Rai

University of Wisconsin-Milwaukee

Dr. Cathy J. Schlund-Vials

University of Connecticut, Storrs

Dr. Nancy J. Smith-Hefner

Boston University

Dr. Yer J. Thao

Portland State University

Dr. Monica M. Trieu

Purdue University

Dr. Silvy Un

Saint Paul Public Schools

Dr. Linda Trinh Vo

University of California, Irvine

Dr. Varaxy Yi Borromeo

California State University, Fresno

Dr. Yang Sao Xiong

The University of Wisconsin-Madison 


\section{Doctoral Student Editorial Review Board}

Diana Chandara
University of Minnesota-Twin Cities
Bao Diep
University of Minnesota-Twin Cities
Vanessa Sovanika Na
University of California San Diego
Khoi Nguyen
George Mason University
Hoa Nha Nguyen
Boston College
Linda Marie Pheng
University of Wisconsin-Madison
Latana Thaviseth
University of California Los Angeles
Melissa Vang
San Diego State University

Diana Chandara

Bao Diep

rsity of Minnesota-Twin Cities

y of California San Diego

rge Mason University

Hoa Nha Nguyen

Boston College

rsity of Wisconsin-Madison

ity of California Los Angeles

San Diego State University

\author{
Kassandra Chhay \\ University of Minnesota-Twin Cities \\ Annie BichLoan Duong \\ San Joaquin County Office of Education \\ Nielson Hul \\ Cornell University \\ Dung Minh Mao \\ University of Minnesota-Twin Cities \\ Thien-Huong Ninh \\ University of Southern California \\ Krissyvan Truong \\ Claremont Graduate University \\ Mai Vang \\ University of Massachusetts Boston \\ Thong Vang \\ University of Minnesota-Twin Cities
}

\section{Soua Xiong}

San Diego State University

Claremont Graduate University 